\title{
Budget Risks of Russian Federation Regions, Determination and the Application in the Budget Process
}

\author{
Julia Vlasova \\ Plekhanov Russian University of Economics \\ Email: ja.vlasova@mail.ru
}

\section{Doi:10.5901/mjss.2015.v6n4s4p362}

Abstract

The article examines the definitions, main features and role of fiscal risks in the budget system. The classification of the budget risks which need to be considered at all stages of the budget process is provided in the paper. Need, and also the positive and negative moments from use of complex system on the identification, analysis and risks assessment are proved during the planning, implementation and forecasting of the budget policy of the region. The comparative overview of the analysis methods of the budget risks is also carried out.

Keywords: budget risks, region budget, government debt, budget policy

\section{Introduction}

The new economic conditions caused by an adverse external economic conjuncture and economic downturn in Russia have a direct impact on the consolidated budget of the Russian Federation. The arising new risks of budgets require specific studying for effective budget policy. The budget of the state as any participant of a financial system has pressure of risks. However relevance of risks accounting has especially increased currently in case of the budget policy of the Russian Federation due to the fact that the deterioration of the political and economic external environment and economic downturn in Russia have led to the emergence of new risks. Budgets of the territorial subjects of the Russian Federation are especially vulnerable in this situation. In view of the above-mentioned factors, it is considered necessary to pay attention to the recognition, identification and assessment of the risks of the territorial subject's budgets of the Russian Federation.

Such factors as decline in investment and the industrial production index, the deterioration of the lending market situation observed in 2015 in Russia lead to decrease in receipts of the tax income in the budgets (the profit tax, the personal income tax and many others), and force the subjects to look for other sources of financing of budget expenses of the territorial subjects of the Russian Federation. With the growth of budgets expenses and possible reduction in income, risks of increase in the subjects' budget deficit and many others can significantly increase. And the observed essential growth of the cumulative debt of the subjects of the Russian Federation can result in vital challenges for regional budgets in the medium-term prospect.

Therefore, in our opinion, at the moment it is impossible to organize effective budgetary planning without careful analysis and an assessment of the budget risks, to implement the budget policy and to develop effective antirecessionary measures.

The purpose of this article is to concretize the concept of the budget risk, to offer the classification of the budget risks drawn with regard to the peculiarities of the regional budgets and to substantiate the need for inclusion of risk identification and assessment methods in the stages of budgetary planning at the regional level.

It is necessary to agree with experts that risks not only reduce efficiency of the implementable policy, but also lead to failure to carry out its conditions (Baldacci et al. 2011). The extremely important place in the risk system is taken by the budget risks as they have negative impact not only on public finances, but also on the economy in general. Methodology and practice of 'budget risks' definition is understudied in the domestic and foreign scientific literature. In our opinion, unsufficient scientific research of the budget risks may result in considerable expenditures of the budget system and decreased efficiency of budget expenses. 


\section{Determination and Classification of the Budget Risks}

\subsection{Legislative control}

The legislation of the Russian Federation has not defined the concept of the budget risk and its types yet; however such concepts even more often, due to their high relevance, occur in separate documents, such as:

1. The Order of the Ministry of Finance of the Russian Federation No. 383 dated 19.10.2011 (as amended on 20.01.2014) "On the Procedure for Operational Monitoring of Financial Management Quality in the Ministry of Finance of the Russian Federation" Appendix No. 1. The Budget Risk Assessment. This appendix even provides the procedure for estimation of budget risks divided into 3 groups: inefficiency of budgeted expenses, low quality of revenue management and inefficient management of liquidity of federal funds expenditure account.

It is obvious that in this document the estimated risks have a strict focus on the assessment of activity within the law enforcement framework. It is also possible to tell that it is rather not risks, but criteria of efficiency evaluation.

2. In the letter of the Ministry of Finance of the Russian Federation No. 02-11-05/932 dated 19.01.2015 "On the Direction of the Methodical Recommendations for Implementation of Internal Financial Control and Methodical Recommendations for Implementation of Internal Financial Audit" the form of the budget risk analysis was offered. This letter defined the risk levels for violations in the field of drawing up, maintaining and administration of budget estimates.

3. The description of the budget risks can be found in clause 2.2 of the Main Lines of the Budget Policy for 2015 and for the Planning Period of 2016 and 2017. "The main macroeconomic and budget risks". These risks are specified not only at the level of the federal subject, but also at the level of subjects.

Nevertheless, risks are simply listed, without support on any systematicity; there is no determination of the budget risk at the legislative level. Thus, there is an objective need for systematization of the theoretical base for the budget risk sphere of the budgets of the subjects of the Russian Federation.

\subsection{Literature review}

The risk is the probabilistic event capable of affecting negatively the implementable policy and predetermining the need for its adjustment (Slepov and Arslanov, 2014). This general definition of risk which is found in the modern literature, most fully reflects the essence of risk for the economy in general at the present stage of development. At the same time, there are some discrepancies in the theoretical definition of the budget risk concept; it is formulated either rather narrowly, or without regard to full suite of factors. Thus, it is obvious that the budget risks are not limited only to the budgetary surplus or the fact of 'insufficient receipt of budget funds' or mismatch between the actual budget performance and the plan (Baksha, Gamukin, Svintsov, 2012). The definition of the budget risk as a "probability of emergence of budget loss due to the impact of the environmental factors and managerial decisions having a negative impact on budget stability, which are subject to quantitative and qualitative assessment" seems interesting (Gorokhova, 2013). However it is also limited because it considers exclusively external factors whereas the budgets of the subjects of the Russian Federation are characterized by the essential influence of internal factors. The internal factors are prevailing for the budgets of the subjects of the Russian Federation (hereinafter referred to as the RF) as the budget revenue which directly depend on the external economic environment such as Mineral Extraction Tax (hereinafter referred to as MET) and export customs duties go into the federal budget of the Russian Federation in full. Thus, external factors have a direct impact on the federal budget and indirect impact on the budgets of territorial subjects of the RF. Also the concept of budget stability cannot refer fully to the budgets of the territorial subjects of the RF as the big share of subjects directly depends on the federal budget, and in this aspect their financial stability cannot be implied initially.

Thus, irrespective of the factors which had a negative impact on the budget, the budget risk represents a broader concept, than simply the risk of budget non-execution. Summing up the above, it is possible to formulate the concept of the budget risk of the territorial subject of the RF as probability of occurrence of such unfavorable event which can lead to violation of the current budget process, to the essential deviation of the main indicators of budget execution from average or planned ones, and, therefore, the need for adjustment of the budget forecasts for the short, average and long-term periods. 


\subsection{Risk classification}

In our opinion, a group of the economic risks including insolvency, liquidity and credit risks should be distinguished in the combination of factors which can be risk for budgets of territorial subjects of the RF. Thus, for the Russian regions the risk of insufficient receipt of the income is a substantial risk during the crisis periods. It is also possible to subsume the risk of insufficient receipt of the tax revenue into this category: revenue from the profit taxes due to deterioration of a financial state of the regional entities and personal income tax due to salary reduction or unemployment growth, vehicle possession tax due to decrease in level of living, etc. Risks of insufficient receipt of the non-tax revenue are, for example, decrease in gain on assets which are owned by the regional authorities, privatization plan non-fulfillment, certain types of charges due to slowdown in economic activity in the region.

The group of economic risks includes also the risks of budget expense growth, budget deficit/surplus growth, increase of dependence on the federal budget, growth of the subject's debt, or change of its structure towards deterioration, that is more encumbering for the budget.

Not only economic factors (risks), but also structural, organizational-technical and social factors are risk-bearing for the budgets of the subjects. Social risks are the risks connected with conducting such government policy that may worsen considerably the status of socially vulnerable groups, which can result in social tension in the society.

The studies of the Russian scientists (Shuvayeva, Tikhonova, 2010) as exemplified by the municipalities showed that implementation of Federal Law No. 131-FZ of 06.10.2003 "On the General Principles of the Organization of Local Self-Government in the Russian Federation" is connected with significant budget risks. One of the first risk moments is that the municipality is at the 'lower' step of the budget vertical and depends on timeliness of the budget process implementation by higher-level bodies of the power and management. The same can be referred to the budgets of the territorial subjects of the RF, since the subjects' budgets belong to the second step of the budget system of Russia.

The risks relating to the execution efficiency of programs, transactions and the other activities connected with implementation of the budget process and the risks of budgetary funds management by particular structures of the subject's governing bodies can be subsumes to the organizational and technical risk group (Fig. 1). These risks are still rather high in modern conditions in Russia.

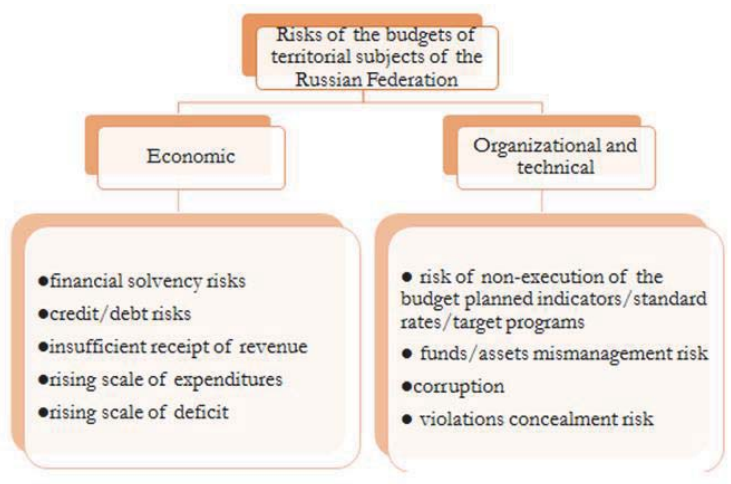

Figure 1. The budget risk system of the subject of the Russian Federation

Division of risks into economic, social and organizational and technical ones is a generalized classification of the budget risks, which, in our opinion, is of theoretical interest. More detailed classification of economic risks is necessary for implementation of a detailed assessment of the budget risks.

\subsection{Internal and external risks}

It should be noted that various factors: internal or external may lead to one and the same risk. Despite an indirect impact of external factors on the subjects' budgets, 2014 showed that external factors can also have essential impact on the budgets of the territorial subjects of the RF. Therefore we distinguished the budget risks of the subjects and factors, influencing them according to the degree of orientation on external and internal ones (Table 1). 
Table 1. Classification of economic budget risk of the territorial subjects of the Russian Federation

\begin{tabular}{|c|c|c|}
\hline Type of risk & External risks & Internal risks \\
\hline \multicolumn{3}{|l|}{ Income risks: } \\
\hline Tax revenue contraction (fiscal) & $\begin{array}{l}\text { Worsening of the external economic situation for } \\
\text { the Russian exporters, reduction of the world } \\
\text { resource prices, imposition of trading sanctions }\end{array}$ & $\begin{array}{l}\text { Risk of high tax burden, deterioration of economic activity, } \\
\text { unemployment growth, salary decrease }\end{array}$ \\
\hline Non-tax revenue contraction & $\begin{array}{l}\text { Imposition of sanctions in relation to the Russian } \\
\text { entities/sectors of the Russian industry }\end{array}$ & $\begin{array}{l}\text { Non-fulfillment of the privatization plan } \\
\text { Weakening of the domestic market }\end{array}$ \\
\hline $\begin{array}{l}\text { Risks relating to the movements in } \\
\text { value of assets and liabilities in } \\
\text { which budgetary funds are placed }\end{array}$ & $\begin{array}{l}\text { Weakening of the stock market as a response to } \\
\text { the shift in the external market conditions }\end{array}$ & $\begin{array}{l}\text { Weakening of the stock market as a local process due to } \\
\text { the monetary policy, inflation and inflation risks }\end{array}$ \\
\hline Risk of FB dependence growth & $\begin{array}{l}\text { Insufficient receipt of revenue due to drop in } \\
\text { production, including due to the shift in the external } \\
\text { market conditions }\end{array}$ & High share of FB funds in the budget revenue of the subject \\
\hline \multicolumn{3}{|l|}{ Expenditure risks: } \\
\hline $\begin{array}{l}\text { Risk of expenditure growth } \\
\text { acceleration }\end{array}$ & $\begin{array}{l}\text { Need for additional financing of anti-recessionary } \\
\text { measures due to negative shifts in the external } \\
\text { economic environment }\end{array}$ & $\begin{array}{l}\text { Inflation and inflation expectations decline in economic } \\
\text { activity, need for additional financing of anti-recessionary or } \\
\text { emergency measures. }\end{array}$ \\
\hline \multicolumn{3}{|l|}{ Debt risks } \\
\hline Debt growth risk & ---- & $\begin{array}{l}\text { Debt growth caused by need for financing of bigger deficit } \\
\text { (decrease in the revenue/growth of expenses), need for } \\
\text { increasing expenses for programs, etc. }\end{array}$ \\
\hline $\begin{array}{l}\text { Risk of a debt structure change } \\
\text { towards indebtedness to the credit } \\
\text { organizations }\end{array}$ & $-\cdots--$ & $\begin{array}{l}\text { Domestic market capacity, lowering of the credit rating of } \\
\text { the region, weakening of the domestic stock market forces } \\
\text { the regions to address to banks }\end{array}$ \\
\hline Government guarantee event risk & --.- & Budget expense increase \\
\hline Loan program reduction risk & $\begin{array}{l}\text { Due to negative shifts in the external economic } \\
\text { environment }\end{array}$ & Weakening of the domestic stock market \\
\hline \multicolumn{3}{|l|}{ Deficit (surplus) risk } \\
\hline $\begin{array}{l}\text { Risk of non-compliance with the } \\
\text { maximum deficit limit }\end{array}$ & ---- & Poor control of expenses/budget revenues \\
\hline Deficit growth risk & $\begin{array}{l}\text { National currency devaluation, negative shifts in the } \\
\text { external economic environment }\end{array}$ & $\begin{array}{l}\text { Inflation and inflation expectations, decline in economic } \\
\text { activity, need for additional financing of anti-recessionary or } \\
\text { emergency measures }\end{array}$ \\
\hline
\end{tabular}

Internal risks are conditioned by an intra-economic situation in the country, peculiarities of its structure and dynamics, availability of emergency situations, characteristic features of budgetary planning and the process. Internal risks also arise or are mitigated due to amendment of the legislation at all levels of the power. In our opinion, such not economic risks as the risk of non-execution of the budget, non-execution of the federal program (for the region), risk of corruption, risk of inefficient cash distribution (budget expenses), risk of inefficient management of the public funds/assets, risk of violation concealment in the budget management, etc. should be referred to the internal risks as well. Statistical methods for analysis showed close interrelation between income behavior of the consolidated budget of territorial subjects of the RF and the tax revenues (85\%), ruble-dollar exchange rates (41\%), Gross Regional Product (98\%).

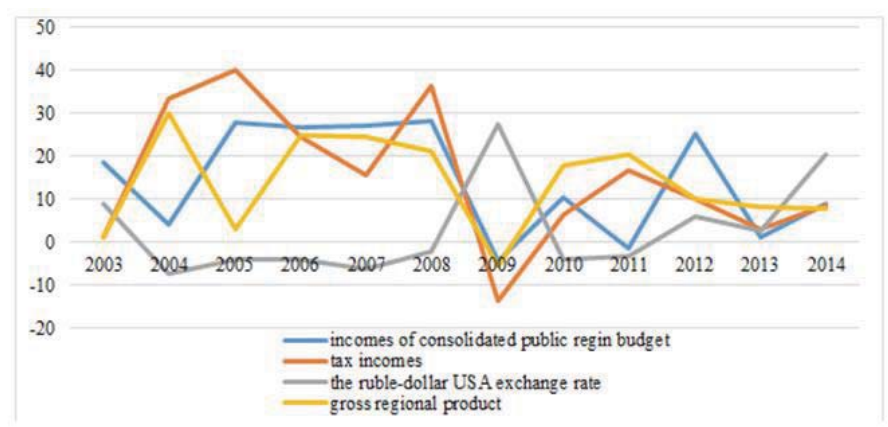

Figure 2. Dynamics of internal factors, $\%$ 
External budget risks are risks action of which is performed from external sector, whether it is worsening of the market situation, including change in import dynamic, reduction of resource prices, trading sanctions. It is important to note once again that though the role of external risks is high now, but nevertheless, they have only an indirect impact on the budgets of the subjects in Russia.

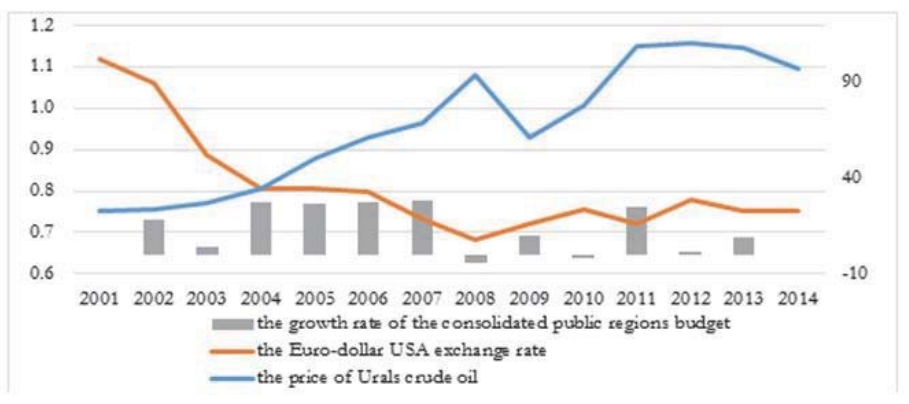

Figure 3. Dynamics of external factors, $\%$

Thus, the indirect impact of external risks on the subjects' budgets reveals structural shortcomings of the Russian economy in general and problems in the effective management of the budget process, in particular.

\section{Risks in the Budget Process}

While the budget systems of the developed countries were analyzed by the IMF experts, they highlighted the necessity to include risk management in the first stage of the budget process (Holger van Eden, 2014). Risk management is a system of risk identification, forecasting and management.

In the conditions of the Russian realities it is necessary to put emphasis on the word 'system'. System approach to the budget risk identification, assessment and management is absent so far in Russia.

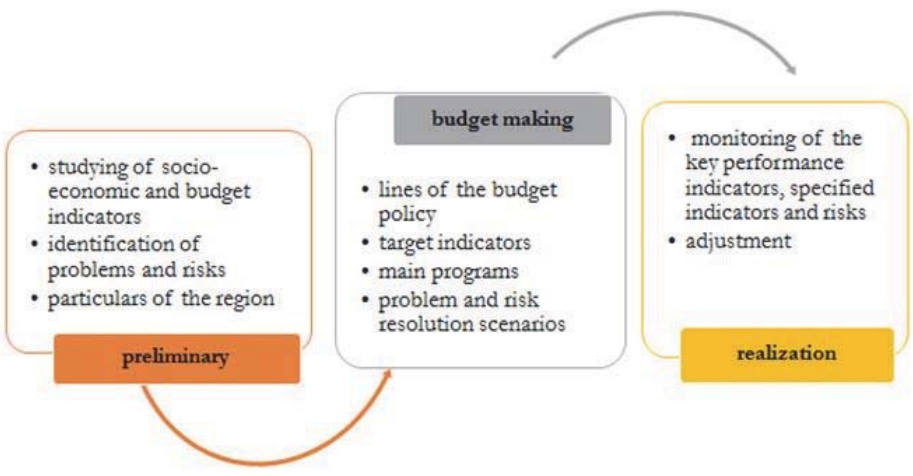

Figure 4. Application of risk-oriented approach at all stages of the budget policy.

At a preliminary stage when the socio-economic and budget indicators of the subject are assessed, the main problems, the priority items of expenditure are identified, target indicators are developed. It is large-scale and difficult work, nevertheless, at this stage, in our opinion, it is necessary to assess possible risks of the subject's budget using predesigned algorithm. On the basis of the obtained data, with regard to the particulars and opportunities of the region transition to the second stage is performed, this stage implies development of the budget policy for the year under planning and the next 3 years.

At the subsequent stage - the implementation of the budget policy - monitoring of socio-economic indicators 
should be performed regarding their deviation from the planned ones, and also the subjects' budget risks should be monitored to prevent the occurrence of events at an early stage.

At the third stage the budget indicators, indicators are adjusted, additional measures for leveling of the support risks are developed proceeding from the risks revealed during monitoring.

Effective application of the above approach to risk assessment and monitoring at all stages of the budget process requires its legislative recognition. In this connection, it is extremely important to apply this approach not on a recommended basis, but on a mandatory one.

Implementation of this approach in practice will allow increasing significantly the efficiency of budget policy implementation and disposal of budgetary funds in the regions, to be more agile and more alert to market changes, to prevent possible consequences of risk occurrence more efficiently, it will increase the forecast quality and will enable to develop short-term and medium-term strategies for the regional budget policy development. Nevertheless this approach can have drawbacks, as well. For development and implementation of monitoring of risks a need arises to introduce amendments into the legal acts, and also to increase the number of persons employed, and, therefore, to increase labor expenses. (Fig. 5)

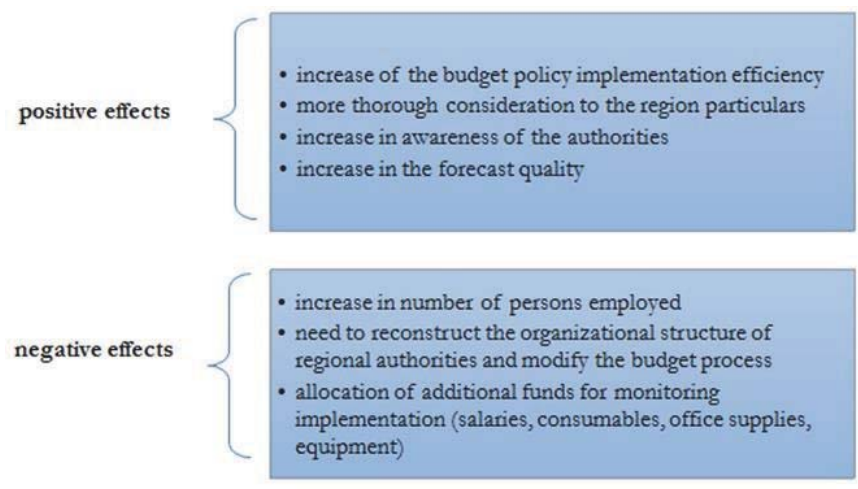

Figure 5. Positive and negative effects due to introduction of budget risk identification and monitoring methods at all stages of the budget process.

The probability of occurrence of any the risks listed in table 1 entails probability of deterioration of the regional budget structure, leads to the need for budget adjustment, development of additional measures for elimination of negative tendencies.

\section{Budget Risk Assessment Methods}

The most widespread methods of budget risks assessment are statistic and econometric methods.

\subsection{Statistic methods}

The essential drawback of statistical methods is insufficiency of data files for construction of an adequate model. Also difficulties can arise due to the complexity in determining the probability of the uncertainty situation outcome (Gorokhova, 2013).

\subsection{Signaling approach}

It is necessary to distinguish signaling approach among the majority of methods for assessment of the budget risks of territorial subjects of the RF. It consists in building a model to study the change of indicators during normal (non-crisis), pre-crisis and crisis periods. The indicators are selected on the basis of the data on changes in their behavior in case of normal functioning of economy and during the crisis periods, and also capabilities to provide the valid signal of crisis onset. This model has certain shortcomings. Thus, for example, because of transformation of external variables there is a 
loss of information on the relative importance of values of variables. Signaling approach ignores correlation between independent variables, negatively influencing construction of a composite index (Tsukarev T.V. and Dmitriyev D. A., 2014), it does not allow applying some statistical tests. However essential advantage of this method is that it can be used on rather long time series. Considering peculiarities of the Russian economy development, domestic researchers seldom have databases with the period of more than 10-15 years.

In these conditions the importance of some econometric models decreases. This approach is a suitable tool of the vulnerability analysis of financial system in general or of public finances in particular. This approach was already applied by the Russian experts for the analysis of public finance stability on the basis of which the fiscal stress index was calculated (Vlasova et al ., 2013).

On the basis of the methodology developed by the IMF experts (Baldacci et al., 2011), the Russian specialists calculated the fiscal stress index for the budget of the enlarged government of the Russian Federation. Research results allowed drawing conclusions on the availability of segments which can bear risks of public finance stability in the shortterm and long-term periods. The fiscal stress index is calculated as follows:

$F_{-}$stress $=\sum \omega_{i} d_{i}(t)$,

$\mathrm{i}-$ an indicator number, $\omega$ - the indicator weight, di $(\mathrm{t})$ - the indicative function assumed as being equal to 1 for indicators which in a year of $\mathrm{t}-1$ exceeded their respective threshold value, and 0 - for the other indicators.

\section{Concluding Remarks}

The budget risks are diverse and extremely important for effective implementation of the budget process and leveling of negative impact of unstable processes in economy. The classification of the regional budget risks suggested by the author in table 1 can be used for budget risk assessment. The degree of dependence of budgets on external and internal budget risks is revealed and substantiated. Justification is given for the necessity to apply risk-oriented approach which will allow increasing the budget policy implementation efficiency of the region by means of signaling approach. The signaling approach will enable to consider peculiarities of each separately taken region. Implementation of this method will allow increasing considerably the quality of the budget policy implementation in the Russian Federation.

\section{References}

Baldacci, E., McHugh, J., Petrova, I. (2011a). Measuring Fiscal Vulnerability and Fiscal Stress: A Proposed Set of Indicators/IMF Working Paper. No. 94

Gorokhova, D. V. (2013). Upravlenie byudzhetnymi riskami subjektov Rossiyskoy Federatii: covremennyy vzglyad i perspektivy razvitiya. [Management of the Budget Risks of the Subjects of the Russian Federation: Modern Viewpoint and Prospects of Development // Financial magazine (pp. 55-62). [in Russian]

Gorokhova, D. V. (2014). Management of the budget risks of the budget system (Abstract of the dissertation thesis) [in Russian]

Holger van Eden. (2014) The Secret Weapon for Fiscal Strength - Strong Budget Institutions I/The Global economic forum of the International Monetary Fund Retrieved from: http://blog-imfdirect.imf.org/2014/05/29/the-secret-weapon-for-fiscal-strength-strongbudget-institutions/

Officially published information of Federal State Statistics Service [in Russian]

Officially published information of Federal Treasury of the Russian Federation. [in Russian]

Officially published information of the Ministry of Finance of the Russian Federation. [in Russian]

Shuvayeva, A.D., Tikhonova, S. S. (2010). Budzhetnyy risk: syshchnost i problemy [Budget Risk: Essence and Problems; // KGTU Bulletin, No. 2. (pp. 39-40). [in Russian]

Slepov, V.A., Arslanov, A.F. (2014). Riski natsionalnoy finansovoy politiki [Risks of National Financial Policy]/ Financial magazine, No.2 (pp.75-80). [in Russian]

Tsukarev, T.V., Dmitriyev, D. A. (2014). Razrabotka agregirovannogo indeksa finansovoy stabilnosti (makroekonomicheskyy podkhod) [Development of an Aggregative Index of Financial Stability (Macroeconomic Approach)]/Bank Bulletin [in Russian] Retrieved from www.nbrb.by/bv/

Vlasov, S. A., Deryugina, E.B., Vlasova, Yu.A. (2013). Issledovanie ustoichivosti gosudarstvennukh finansov Rossii v kratkosrochnom I dolgosrochnom periodakh [Research of Stability of Public Finances of Russia in the Short-term and Long-term Periods. I Questions of Economics, No.3 (pp. 33-49) [in Russian] 